\title{
The Effect of Using the Think Pair Share Model Toward Students' Mathematic Communication Ability Derived from Their Leaning Motivation
}

\author{
Muhammad Abdi ${ }^{1}$, Zulkifli Nelson ${ }^{2}$, Hasanuddin ${ }^{3}$ \\ ${ }^{1}$ Universitas Riau, INDONESIA \\ ${ }^{2}$ Universitas Islam Negeri Sultan Syarif Kasim Riau, INDONESIA \\ ${ }^{3}$ Universitas Islam Negeri Sultan Syarif Kasim Riau, INDONESIA
}

\section{ARTICLE'S \\ INFORMATION}

\section{Article history:}

Received: Nov-17-2021

Reviewed: Dec-05-2021

Accepted: Dec-24-2021

$\begin{array}{lr}\text { Keywords: } & \text { Learning } \\ \text { Motivation, Mathematical } \\ \text { Communication Ability, } \\ \text { Think Pair Share }\end{array}$

\section{Corresponding address:}

Muhammad Abdi, E-mail: abdireuss@gmail.com

\begin{abstract}
This research is based on students' low mathematical communication ability and the Think Pair Share (TPS) learning model at State Junior High School 4 Tambang. This research aimed to investigate whether there was a difference in mathematic communication ability between students taught by using the TPS learning model and those taught by using conventional learning derived from their learning motivation at State Junior High School 4 Tambang. This research was a Quasiexperiment aiming at investigating the causality through giving the treatment on one of the classes and comparing the result with another class given different treatments. T-test, Product moment correlation, and Two way Anova were the techniques of analyzing the data. Based on the research findings, it could be concluded that (1) there was a difference in mathematic communication ability between students taught by using the TPS learning model and by using conventional learning, (2) there was a difference in student learning motivation between experimental and control groups, (3) there was a contribution between learning motivation and mathematic communication, and (4) there was no interaction between learning model and student motivation toward student mathematic communication ability.
\end{abstract}

\section{INTRODUCTION}

Mathematics is a universal science that underlies the development of modern technology, is important in various disciplines, and can develop human thinking power. For the scientific world, mathematics is a symbolic language that allows accurate and precise communication. Mathematics, as one of the sciences that must be studied at every level of education has an abstract object. This should not be a reason for students to be afraid of mathematics, but instead, make students challenged always to learn it. Indeed, the abstract nature of mathematical objects is the location of the power in mathematics itself, which allows it to be applied in various contexts [1]. Learning mathematics in schools is expected to be a fun activity. It involves students actively communicating in the learning process, not being bored with learning mathematics. One of the objectives of learning mathematics, according to Permendiknas No. 22 of 2006 which communicate ideas with symbols, tables, diagrams, or other media to clarify problems [2]. The ability of students to communicate ideas with symbols, tables, diagrams, graphs, or pictures is one of the mathematical communication skills.

Related to mathematical communication, the NCTM states that the standard abilities that students should master are as follows: (a) organize and consolidate mathematical thinking and communicate to other students, (b) express mathematical ideas coherently and clearly to other students, teachers, and others, (c) improve and expand students' mathematical knowledge by thinking 
about other students' thoughts and strategies, and (d) use mathematical language appropriately in various mathematical expressions [3].

Mathematical communication skills in Indonesia are still relatively low. This is known from the international survey The Trend International Mathematics and Science Study (TIMSS). From the TIMSS international survey results in 2011, Indonesia is ranked 38th out of 63 in learning mathematics. Aspects assessed in mathematics are knowledge of facts, procedures, concepts, application of knowledge, and understanding of concepts, according to reports on the results of international studies $47 \%$. When compared to other countries, Indonesia's ability to translate questions into the language of mathematical ideas, diagrams, or graphs is still below average.

Meanwhile, the Program for International Student Assessment (PISA) Survey, a program of the world economic cooperation and development organization (OECD), shows that in 2009, Indonesian student achievement was in position 68 out of 74 countries surveyed. The average score of students' abilities in other areas is 496. The aspects assessed in PISA are understanding, problemsolving, reasoning, and communication skills.

Based on research conducted by Gusti Hanafi, the causes of students being unable to communicate mathematical knowledge into questions are the lack of teacher creativity in creating more interesting learning, the use of learning methods that are not in accordance with what is expected, the level of students' ability to communicate mathematics into vary questions. So that students are less interested in learning mathematics which makes it difficult for students to communicate their knowledge in the questions given and has a negative impact on learning outcomes [4].

Based on the observation of learning mathematics at SMP Negeri 4 Tambang, it was obtained that learning, in general, is conventional. It appears that learning has not been student-centered (student-centered learning). Students receive the material presented by the teacher actively by taking notes, and only a few students express opinions or ask verbally related to the material. If you study the syllabus and the Lesson Plan (RPP) used in learning mathematics at SMP Negeri 4 Tambang, the components already refer to the KTSP. However, the essential events that occur in students still act as objects of learning, not as subjects of learning.

Based on the results of observations of mathematics learning at SMP Negeri 4 Tambang, the lack of students' mathematical communication skills can be seen from (1) the lack of students' ability to express mathematical ideas in the form of pictures and graphs, (2) the lack of student expression in making models. Mathematics, (3) low writing skills, namely the ability to provide mathematical explanations incorrect and easy-to-understand language, (4) in the discussion process, only a few students are willing to speak and tend to be students who are the same, (5) only a small number of students who dared to explain the questions from the teacher to their friends, and (6) at the end of the lesson the students had not been able to make conclusions.

Based on these problems, students' mathematical communication skills must be improved. To be realized, a teacher must strive to increase student learning motivation. In addition, learning motivation needs to be improved and improving the use of learning strategies in the mathematics learning process. In learning mathematics, the approach that is often used is the conventional approach, so the learning process activities are centered on the teacher. The habit of being passive and lacking motivation in the learning process can result in most students being afraid and embarrassed to ask the teacher about material that is not understood. The learning atmosphere in the classroom becomes very monotonous and less interesting. Designing learning that familiarizes students to construct their thoughts with teachers, friends, and the mathematics material itself is 
necessary. One way that can be done to improve students' mathematical communication skills is to apply the right learning model. Another way that is considered appropriate to develop students' mathematical communication skills is group discussion. Group discussions allow students to construct their knowledge so that it is easier to understand the concepts being taught and communicate their ideas in oral and written form. One alternative to support this is to apply the cooperative learning model. Cooperative learning is a learning system that seeks to utilize peers (other students) as a source of learning, in addition to teachers and other sources [5].

The cooperative learning model has several types. One type of cooperative learning model that can encourage active participation of students in the classroom is the Think Pair Share type of cooperative learning model. Think Pair Share cooperative learning model is one type of cooperative learning model that provides opportunities for each student to show participation to others [6].

According to Thobroni, "this TPS learning model provides more opportunities for students to work alone as well as work together with other friends [7]." Trianto also stated that "Think Pair Share technique or think-pair-share is a type of cooperative learning designed to influence interaction patterns and student optimization" [8]. Likewise, Anita Lie stated that "The Think Pair Share technique allows students to work alone and collaborate with others, besides that another advantage of this technique is the optimization of student participation" [9].

Based on research conducted by Husna with the title Improving Problem Solving and Mathematical Communication Ability of Junior High School Students Through Cooperative Learning Model Type Think Pair Share (TPS). This study indicates that the increase in students' mathematical communication skills using Think Pair Share cooperative learning is better than students who receive conventional learning. Yunita Ela Rizki conducted another study titled The Effect of the Implementation of Think Pair Share (TPS) Learning Model on Students' Mathematical Communication Ability [10]. This study indicates that students using the Think Pair Share cooperative learning model are better than students using conventional learning. Another study was also conducted by Jenni Vitriani entitled The Effect of the Application of Think Pair Share (TPS) Cooperative Learning Model on Students' Mathematical Communication Ability. This study indicates that the mathematical communication skills of eighth-grade students of SMP Negeri 13 Padang in the 2013/2014 academic year who learn using the Think Pair Share cooperative learning model are better than conventional learning [9].

Prastya Irawan in Agus Suprijono said that of the three factors that influence learning achievement, namely family background, school conditions or context, and motivation, the last factor is the best. Welberg et al. concluded that motivation contributes between 11 and 20 percent of learning achievement [11]. It should also be remembered that each student has different learning motivations. Some students have high learning motivation, and some have low learning motivation. Therefore, every teacher must be able to motivate students in learning so that the motivation for each student is stimulated optimally to achieve learning achievement. According to Rasyad, motivation means the art of encouraging students to carry out learning activities so that learning objectives are achieved [6]. This understanding emphasizes the teacher's efforts to provide external motivation to stimulate students to be more active in learning. Based on the description, it shows that motivation has a relationship between motivation and student learning outcomes.

Communication is very important for humans. For human life from day to day, humans are never separated from communication. Communication can occur in various contexts of life, including the world of education. Communication in the world of education occurs both between educators and students and between fellow students. 
Mathematical communication can be interpreted as an event of mutual relationship/dialogue in a classroom environment, where there is a transfer of messages [12]. The transferred message contains the mathematics material learned in class and communication in the classroom environment between the teacher and students. Meanwhile, transferring messages can be written or verbally conveyed by the teacher to students for mutual communication so that communication can run smoothly and vice versa. If communication between students and teachers does not work properly, there will be low mathematical communication skills.

According to the Vermont Department of Education in 2004, mathematical communication involves three aspects, namely: (a) using accurate mathematical language and using it to communicate aspects of problem-solving, (b) using mathematical representations accurately to communicate problem-solving, (c) presenting well-organized and structured problem-solving.

Related to mathematical communication, the NCTM states that the standard abilities that students should master are as follows: (a) organize and consolidate mathematical thinking and communicate to other students, (b) express mathematical ideas coherently and clearly to other students, teachers, and others, (c) improve and expand students' mathematical knowledge by thinking about other students' thoughts and strategies, and (d) use mathematical language appropriately in various mathematical expressions [4].

Indicators that show mathematical communication skills are: (a) linking real objects, pictures, and diagrams into mathematical ideas, (b) explaining mathematical ideas, situations, and relations, orally or in writing with real objects, pictures, graphs, and algebra. (c) expressing everyday events in mathematical language or symbols, (d) reading with the understanding of a mathematical presentation, and (e) reading with a written mathematical percentage [6].

Based on the explanation that has been presented, it can be concluded that the criteria for good mathematical communication are if it meets all the indicators mentioned in the previous description. But in this study, what will be discussed in mathematical communication skills which are written well and are said to be good if they meet the following indicators: (a) drawing skills, including students' ability to express ideas in the form of graphs, pictures, and diagrams, (c) the ability to write (written text), including the ability to provide mathematical explanations and reasons with mathematical language that is correct and easy to understand, and (c) the ability to express mathematics (a mathematical expression), including the ability to make mathematical models.

Think Pair Share is a cooperative learning model that gives students time to think, respond, and help each other [13]. So, in the Think Pair Share type of cooperative learning, students have more time to think about answers to questions/problems posed by the teacher, students are allowed to respond to answers put forward by their friends, and students are trusted to help their friends on various occasions, be it in completing assignments and in understanding the subject matter.

Think Pair Share is a simple but useful method developed by Frank Lyman of the University of Maryland [7]. Trianto stated that "Think Pair Share is an effective way to vary the atmosphere of class discussion patterns." Assuming that all discussions require arrangements to control the class as a whole and the procedures used in Think Pair Share can give students more time to think to respond and help each other [8].

Trianto further stated: "Think Pair Share technique or think-pair-share is a type of cooperative learning designed to influence interaction patterns and student optimization" [8]. It was also emphasized by Lie that "The Think Pair Share technique allows students to work alone and collaborate with others, besides that another advantage of this technique is the optimization of student participation" [9]. 
Cooperative learning with the Think Pair Share model will improve students' mathematical communication skills and the ability to understand difficult concepts with their peers. The teacher is tasked with completing the student's brief presentation when explaining the assignment.

According to Nanang Hanafiah, the steps that can be taken in this teaching model are as follows: (1) the teacher conveys the core material and competencies to be achieved, (2) students are asked to think about the material or problems presented by the teacher, (3) Students are asked to pair up with their next-door friend (group of 2 people) and express their respective thoughts, (4) the teacher leads a small plenary discussion, each group presents the results of the discussion, (5) begins with the activity directing the conversation on the subject matter and adding material the students have not revealed, (6) the teacher gives conclusions, and (7) closing [14].

So, at first, the students think for themselves (think) the problems given by the teacher, then in the pair stage, students work together to discuss the best answers according to them. The next stage is the sharing stage to presents the answers in groups in front of the class.

After presenting in front of the class, students will feel the deep benefits of this technique, where they can solve problems from different perspectives but lead to the same answer. This model can improve students' ability to participate in the teaching and learning process, so that students will interact better in class and be able to express opinions in class. The ability to express this opinion is one way for students to understand the material being given by the teacher. The form of expressing this opinion can be in a question, but it can also be in the form of a statement. The advantages of Think Pair Share include: (a) it can provide opportunities for students to collaborate with others, (b) can optimize student participation during the learning process, (c) it can be used in all subjects at all age levels of students [9].

In addition to having advantages, Think Pair Share type Cooperative Learning also has disadvantages. The disadvantages of the Think Pair Share learning model are: (a) it requires simultaneous coordination of various activities, (b) it requires special attention in the use of the classroom, and (c) the transition from the whole class to small groups can take up valuable teaching time. For this reason, teachers must be able to do careful planning to minimize the amount of time wasted [7].

Motivation and learning are two things that influence each other. The term motivation comes from the word motive, which can be interpreted as the power contained within the individual, which causes the individual to act or do [12]. This confirms that motives cannot be observed directly but can be interpreted from their behavior in encouragement, stimulation, or power generation to do something.

Sardiman said that motive is defined as an effort that encourages someone to do something. Motives can be interpreted as a driving force from within and within the subject to carry out certain activities to achieve a goal [15]. In teaching and learning activities, motivation is said to be the overall driving force in students that causes learning activities, which will ensure the continuity of student learning activities and provide direction to their learning activities so that the desired goals of students can be achieved.

According to Mc. Donald in Sardiman, motivation is a change in energy in a person which is characterized by the emergence of feelings that are preceded by a response to the existence of a goal to be achieved [15]. Oemar Hamalik said that motivation is a change in energy in a person's personality, characterized by the emergence of feelings and reactions to achieve goals [16].

Based on some of the opinions that have been described, motivation can be concluded as an impulse that exists within the individual, giving rise to behavior to maintain it, providing energy and 
a certain direction to achieve the desired goal, including the behavior of learning mathematics.

Learning is a relatively permanent behavior change that occurs due to practice or reinforcement (motivation) based on a specific goal. So, learning is a change in behavior resulting from an individual practice through a process of interaction with the environment.

Motivation to learn at first is a natural tendency found in the individual. Learning motivation is a non-intellectual psychological factor. Its role is to foster enthusiasm and a sense of pleasure to learn. The essence of learning motivation is internal and external encouragement to individuals learning to act.

Based on the understanding described, it can be concluded that, in essence, the motivation to learn mathematics is an internal and external drive that changes the energy in individuals to drive behavior and maintain it. So there is a change in behavior that leads to math learning activities.

Learning motivation plays an important role in the achievement of learning mathematics achievement. Hamzah B. Uno describes four important roles of motivation in learning, including (1) determining things that are used as learning reinforcements, (2) clarifying the learning objectives to be achieved, (3) determining various kinds of control over learning stimuli, and (4) determine student learning persistence [12].

Motivation is closely related to the goals to be achieved, so motivation also affects the activities to be carried out. In this regard, Sardiman argues that learning motivation functions to encourage people to act, determine the direction of action, and select which actions to take. In addition, learning motivation can function as a driver of effort and achievement of learning. In other words, motivation will cause perseverance in a person and give birth to good achievements. The intensity of student learning motivation will determine students' mathematical communication level of achievement.

Meanwhile, according to Oemar Hemalik, motivation is to encourage behavior. Without motivation, there will be no action like learning. Motivation also functions as an influence that will mobilize one's actions to achieve the desired goal. Motivation also functions as a driver. The level of motivation will affect the speed at which students learn [12].

Based on this description, it can be concluded that the motivation to learn mathematics is very important. This can be seen from the role and function of learning motivation itself, namely as a driver, influence, and motivator of students to carry out their learning activities so that the results achieved are optimal. Each student has a different learning motivation. Some students have high learning motivation, and some have low learning motivation.

Some indicators or elements that support learning motivation are as follows: (a) the desire and desire to succeed, (b) the encouragement and need for learning, (c) the hopes and aspirations of the future, (d) the appreciation in learning, (e) the existence of interesting activities in learning, and (d) the existence of a conducive learning environment that allows a student to learn well.

Sardiman also wrote that students who have learning motivation have the following characteristics: (a) persistence in dealing with assignments, students can work continuously for a long time and do not stop before finishing work, (b) tenacious in facing difficulties (not easy). Desperate), (c) showing interest in various problems that occur in everyday life, (d) preferring to work alone, (e) getting bored quickly with the same routine tasks, (f) being able to defend his opinion, ( $\mathrm{g}$ ) it is not easy to let go of things that are already believed, and (h) happy to find and solve problems contained in the practice questions.

So, in general, it can be concluded that indicators of students' motivation to learn mathematics include: the desire and desire to succeed, the drive and need to learn, the hopes and aspirations for the future, tenacity in facing difficulties, showing interest in various problems, prefers to work alone, 
gets bored quickly on routine tasks, can defend his opinion, likes to find and solve problems, likes to follow lessons, is diligent in learning and facing math assignments. The researcher took a criterion to determine the students' initial abilities.

\section{METHODS}

This research is quasi-experimental, and the Nonequivalent Control Group design is used. An overview of this design is as follows:

$\begin{array}{lll}\mathrm{O} 1 & \mathrm{X} & \mathrm{O} 2 \\ \mathrm{O} 3 & \mathrm{X} & \mathrm{O} 4\end{array}$

With

O1, O3 : Pretest

$\mathrm{X} \quad$ : Treatment with Think Pair Share model

O2, O4 : Posttest

\section{RESULTS AND DISCUSSION}

To see if there is a difference in mathematical communication skills between students who use cooperative learning with Think Pair Share Model and students who use conventional learning, an analysis using the t-test is performed. Based on the results of the analysis, the results of the value of $\mathrm{t} 0=2.696$, greater than the value of ttable for a significance level of $5 \%$, which is 2.00404 , it can be concluded that there are differences in mathematical communication skills between students who apply cooperative learning with the Think Pair Share model and students who apply conventional learning.

Based on observations during the learning process, the Think Pair Share learning model can bring up the courage of students to appear in front of the class, solve problems and explain them systematically to other students' friends. Students are also eager to find solutions with group pairs in discussions, motivating students to be more active in the learning process.

Furthermore, to see whether there are differences in the motivation to learn mathematics between students who use cooperative learning with Think Pair Share Model and students who use conventional learning, an analysis using the t-test is performed. Based on the results of the analysis, it was found that the value of $t 0=2.81$, greater than the value of ttable for a significance level of $5 \%$, which is 2.00404 , it can be concluded that there are differences in the motivation to learn mathematics between students who apply cooperative learning with the Think Pair Share model with students who apply conventional learning.

In addition, to see how big the contribution of students' learning motivation to mathematical communication between students who use the Think Pair Share model of cooperative learning and students who use conventional learning is analyzed using Pearson's relation. Based on the analysis results, the motivation to learn mathematics contributes strongly to students' mathematical communication skills, where motivation contributes $42.29 \%$ to communication skills, and other variables determine the remaining $47.71 \%$.

In addition, to see the interaction between the Think Pair Share model in terms of student learning motivation on learning outcomes, it was obtained 1.108336861. If $\mathrm{F}_{\text {table }}$ confirms this figure with $\mathrm{dk} 2$ for the numerator and 51 for the denominator, the number is 3.16 for a significance level of $0.05(5 \%)$, then it can be seen that Fratio $>\mathrm{F}_{\text {table. }}$ The alternative hypothesis $(\mathrm{Ha})$ is rejected, and the null hypothesis (Ho) is accepted. Where there is no interaction model of learning and motivation, in other words, the students' mathematical communication ability due to the influence of the learning 
model does not depend on the student's motivation rating and student communication because the influence of the motivational rating does not depend on the learning model.

\section{CONCLUSIONS AND SUGGESTIONS}

The conclusions obtained from this study are as follows.

1. The Think Pair Share model of cooperative learning in mathematics is better than conventional learning. From the difference, implementing cooperative learning in the Think Pair Share mode affects mathematical communication skills.

2. There are differences in motivation between students using the Think Pair Share model and students who follow conventional learning.

3. There is a contribution of student motivation to mathematical communication skills.

4. There is an effect on applying Problem Based Learning (PBL) KKM for class VII students in all SMP Negeri students in the Kuantan Singingi Regency.

5. There is no interaction between the Think Pair Share model and mathematical communication in student motivation.

\section{REFERENCE}

[1] A. Jihad, Pengembangan Kurikulum Matematika. Bandung: Multi Pressindo, 2008.

[2] Kementerian Pendidikan dan Kebudayaan, Standar Isi Untuk Satuan Pendidikan Dasar dan Menengah. Indonesia, 2006.

[3] A. Mahmudi, "Komunikasi Dalam Pembelajaran Matematika," . J. MIPMIPA UNHALU, vol. 8, no. 1, pp. 1-9, 2009.

[4] M. Darkasyi, R. Johar, and A. Ahmad, "Peningkatan Kemampuan Komunikasi Matematis dan Motivasi Siswa dengan Pembelajaran Pendekatan Quantum Learning pada Siswa SMP Negeri 5 Lhokseumawe," J. Didakt. Mat., vol. 1, no. 1, pp. 21-34, 2014.

[5] W. Made, Strategi Pembelajaran Inovatif Kontemporer: Suatu Tinjauan Konseptual Operasional. Jakarta: Bumi Aksara, 2009.

[6] A. Rasyad, Teori Belajar dan Pembelajaran. Jakarta: UHAMKA Press, 2003.

[7] M. Thobroni, Belajar \& Pembelajaran Teori dan Praktik. Yogyakarta: Ar-Ruzz Media, 2015.

[8] T. I. B. Al-Tabany, Mendesain model pembelajaran inovatif, progresif, dan kontekstual. Jakarta: Kencana Prenadamedia Media Group, 2014.

[9] J. Vitriani, "Pengaruh Penerapan Model Pembelajaran Kooperatif Tipe Think Pair Share (TPS) Terhadap Kemampuan Komunikasi Matematika Siswa Kelas VIII SMPN 13 Padang Tahun Pelajaran 2013/2014)," Universitas Negeri Padang, 2014.

[10] Y. E. Rizki, Nurhanurawati, and P. Gunowibowo, "PENGARUH PENERAPAN MODEL PEMBELAJARAN KOOPERATIF TIPE THINK PAIR SHARE (TPS) TERHADAP KEMAMPUAN KOMUNIKASI MATEMATIS SISWA (Studi pada Siswa Kelas X Semester Ganjil SMK Muhammadiyah 2 Bandar Lampung Tahun Pelajaran 2012/2013)," J. Pendidik. Mat., vol. 2, no. 1, pp. 37-44, 2013.

[11] A. Suprijono, Cooperative Learning Teori dan Aplikasi P AIKEM. Yogyakarta: Pustaka Pelajar, 2009.

[12] H. B. Uno, Teori Motivasi dan Pengukurannya. Jakarta: Bumi Aksara, 2007.

[13] A. Shoimin, 68 Model Pembelajaran Inovatif dalam Kurikulum 2013. Yogyakarta: Ar-Ruzz Media, 2014.

[14] N. Hanafiah and C. Suhana, Konsep Strategi Pembelajaran. Bandung: PT Refika Aditama, 2012.

[15] A. M. Sardiman, Interaksi dan Motivasi Belajar Mengajar. Jakarta: Rajawali Pers, 2018.

[16] O. Hamalik, Proses Belajar Mengajar. Jakarta: Bumi Aksara, 2008. 


\section{BIOGRAPHY}

Muhammad Abdi

Muhammad Abdi was born on Langgam, Mei 12, 1995. Kec. Rumbio Jaya Kab. Kampar. Elementary to high school education is taken in the Birth Village. Bachelor of Mathematics Education (S1) was taken at UIN SUSKA Riau and graduated in 2017. In 2017 she continued his education and obtained a Master in Mathematics Education (S2) from Universitas Riau in 2021.

Zulkifli Nelson

Zulkifli Nelson was born on July $9^{\text {th }} 1963$. He is a lecturer in Mathematics Education Program, Universitas Islam Negeri Sultan Syarif Kasim Riau. Email: kamp_guntung@yahoo.co.id.

Hasanuddin

Hasanuddin was born on May $26^{\text {th }} 1978$. He is a lecturer in Mathematics Education Program, Universitas Islam Negeri Sultan Syarif Kasim Riau. Email: hasanuddin@uin-suska.ac.id. 